\title{
STUDI KORELASI RELIGIUSITAS TERHADAP ADAB SISWA DI MAN 1 KABUPATEN BOGOR
}

\author{
Winda Misniaty, Hidayah Baisa \\ Universitas Ibn Khaldun Bogor
}

\begin{abstract}
The purpose of this study is to find out the religiosity, the adab of the student, and how much religiosity correlates with the adab of the student. This research was conducted in MAN 1 Bogor Regency. Research uses a quantitative approach with correlation methods. The research data was taken using a questionnaire of religiosity and student adab. Sampling using random sampling techniques. The data collection tool used in this study is a poll using the likert scale. Data analysis using product moment correlation technique. After the researchers tested the research hypothesis, the researchers obtained the results of the study as worship: 1) Religiosity of students in MAN 1 Bogor District has good value in terms of religion, practice of worship, morality, religious knowledge, and delusion with an average score of $85.25 \%$. 2) Students in MAN 1 Bogor District have a good adab against Allah SWT, parents, teachers, themselves and their friends with an average score scale of $82.4 \%$. 3) Religiosity affects students in MAN 1 Bogor Regency, with the influence data being $36 \%$ and $64 \%$ influenced by other factors.
\end{abstract}

Keywords: Religiosity, Adab, Student

\section{PENDAHULUAN}

Agama adalah salah satu unsur terpenting dalam kehidupan seseorang. Tokoh ilmu jiwa agama W.H. Clark mengungkapkan bahwa, tidak ada yang lebih sukar mencari katakata, kecuali menemukan kata yang sepadan untuk menjelaskan definisi agama yang penuh kegaiban dan misteri serta interpretasi.

Dalam bahasa Al-Qur'an, agama sering disebut ad-din artinya hukum, kerajaan kekuasaan, tuntunan, pembalasan dan kemenangan. Dari beberapa arti tersebut dapat disimpulkan bahwa agama (ad-din) adalah hukum serta i’tibar (contoh/pemisalan/ajaran) yang berisi tuntunan cara penyerahan mutlak dari hamba ke Tuhan Yang Maha Pencipta melalui susunan pengetahuan dalam pikiran, tingkah laku yang di dalamnya tercakup akhlaqul karimah (akhlak mulia) yang di dalamnya meliputi moral, susila, etika, tata krama, budi pekerti, terhadap Tuhan, serta semua ciptaan-Nya: kitab suci-Nya, malaikatNya, rasul-Nya, manusia termasuk untuk dirinya sendiri, hewan serta benda di sekitarnya atau ekologinya. ${ }^{1}$

Dalam kehidupan sehari-hari manusia memerlukan pengontrol diri dalam bertingkah laku, bersikap dan bertindak dengan cara mengamalkan nilai yang sudah menjadi aturan atau kewajiban yaitu dengan keagamaan seseorang atau religiusitas.

\footnotetext{
${ }^{1}$ Rusmin Tumanggor, Ilmu Jiwa Agama, 2014
} 
Salah satu potensi yang dapat dikembangkan siswa yaitu pengontrol diri yang bisa diaktualisasikan oleh tingkah laku, akhlak dan adab sehari-hari. Oleh sebab itu adab dianggap penting karena jatuh bangunnya Umat Islam tergantung sejauh mana mereka dapat memahami dan mengamalkan konsep adab dalam kehidupan sehari-hari. Manusia yang beradab terhadap orang lain akan paham bagaimana mengenali dan mengakui seseorang sesuai dengan harkat dan martabatnya. Adab memiliki peran sentral bagi dunia pendidikan. Tanpa adab, dunia pendidikan akan berjalan tanpa ruh dan makna. Lebih dari itu, salah satu penyebab utama hilangnya keberkahan dalam dunia pendidikan yaitu kurangnya perhatian para civitas akademik dalam masalah adab.

Dalam Agama Islam, pendidikan sangat diperhatikan dengan serius. Hal itu terbukti dari banyaknya ayat Al-qur'an yang membahas tentang pendidikan, seperti firman Allah SWT yang meninggikan derajatnya orang-orang yang berilmu dalam surat Al-Mujadilah ayat 11, yaitu:

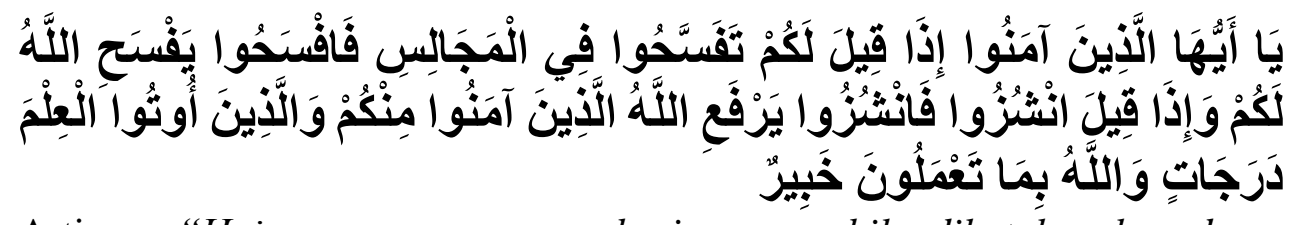

Artinya; "Hai orang-orang yang beriman, apabila dikatakan kepadamu: "Berlapang-lapanglah dalam majelis", maka lapangkanlah, niscaya Allah akan memberi kelapangan untukmu. Dan apabila dikatakan: "Berdirilah kamu, maka berdirilah, niscaya Allah akan meninggikan orang-orang yang beriman di antaramu dan orang-orang yang diberi ilmu pengetahuan beberapa derajat. Dan Allah Maha Mengetahui apa yang kamu kerjakan"(Q.S Al-Mujadilah: 1)

Pada masa dewasa ini, siswa kurang memperhatikan adab, padahal jika diukur kemampuan kognitifnya mereka memahami tentang pengetahuan keagamaan. Jarak antara pemahaman keilmuan dan implementasinya merupakan masalah besar yang dihadapi oleh umat saat ini. Para siswa tidak lagi mencerminkan keilmuannya.

Melihat kondisi pendidikan saat ini, seorang siswa tidak lagi memiliki kecerdasan spiritual yang tinggi, bahkan mereka tidak dapat lagi memanfaatkan ilmu yang mereka dapat. Masalah seperti ini sangat memprihatinkan dan memerlukan solusi yang diharapkan dapat membantu mengantisipasi sikap siswa yang dilanda dengan krisis adab.

Jika pendidikan bertujuan untuk menanamkan adab kepada murid, maka sudah sewajarnya dalam proses belajarnya pun murid harus senantiasa mengamalkan nilai-nilai adab tersebut. Pentingnya memahami adab dalam proses belajar seorang murid adalah sama pentingnya seperti memahami tujuan pendidikan itu sendiri. Hal tersebut terjadi karena dalam proses belajar seorang murid memiliki peluang untuk menentukan keberhasilan dari proses pembelajaran.

Tujuan pendidikan islam pada umumnya berpusat pada upaya pembentukan manusia yang paripurna (insan kamil) yaitu dengan indikator: menjadi hamba Allah, 
menjadi khalifah, menjadi rahmat bagi semesta alam, menjadi uswatun hasanah, dan untuk kesejahteraan hidup.

Religiusitas bisa menjadi salah satu solusi dari adab yang kurang baik. Untuk itu salah satu misi MAN 1 Kabupaten Bogor yaitu mewujudkan kehidupan yang religius di lingkungan madrasah yang ditandai dengan prilaku shalih, ikhlas, tawadhu, kreatif dan mandiri. Namun, masih ada banyak siswa yang belum mencerminkan sikap religius tersebut. Dalam penelitian ini peneliti akan memaparkan korelasi antara religiusitas terhadap adab siswa di MAN 1 Kabupaten Bogor. Berdasarkan latar belakang masalah sebagaimana diungkapkan di atas, maka dapat dijadikan sebagai rumusan masalah berikut: 1). Bagaimanakah religiusitas siswa di MAN 1 Kabupaten Bogor?, 2). Bagaimanakah adab siswa di MAN 1 Kabupaten Bogor?, 3). 3. Bagaimanakah korelasi antara religiusitas terhadap adab siswa di MAN 1 Kabupaten Bogor?

Berdasarkan perumusan masalah di atas, maka tujuan dari penelitian ini adalah 1). Untuk mengetahui religiusitas siswa di MAN 1 Kabupaten Bogor, 2). Untuk mengetahui adab siswa di MAN 1 Kabupaten Bogor, 3). Untuk mengetahui korelasi antara religiusitas terhadap adab siswa di MAN 1 Kabupaten Bogor.

\section{METODE PENELITIAN}

Rancangan penelitian yang digunakan dalam penelitian ini adalah penelitian kuantitatif. Penelitian kuantitatif adalah cara ilmiah untuk mendapatkan data dengan tujuan dan kegunaan tertentu. ${ }^{2}$ Untuk memperoleh data yang diperlukan dalam pembahasan ini peneliti menggunakan metode korelasi. Menurut Nana Syaodih (2010) penelitian ditunjukan untuk mengetahui hubungan suatu variabel dengan variabelvariabel lain. Hubungan antara satu dengan variabel lain dinyatakan dengan besarnya koefisien korelasi (bivariat) dan keberartian (signifikan) secara statistik. Adanya korelasi antara dua variabel atau lebih, tidak berarti adanya pengaruh atau hubungan sebab akibat dari suatu variabel terhadap variabel lainnya ${ }^{3}$.

\section{A. Sampel Penelitian}

Sampel adalah bagian dari populasi yang mempunyai ciri-ciri atau keadaan tertentu yang akan diteliti. Karena tidak semua data dan informasi akan diproses dan tidak semua orang atau benda akan diteliti tetapi cukup dengan sampel yang mewakilinya. ${ }^{4}$ Suharsimi Akunto menjelaskan dalam bukunya jika jumlah subjek besar (diatas 100 orang), dapat diambil antara 10$15 \%$ atau $20-25 \%$ atau lebih ${ }^{5}$. Oleh karena itu peneliti akan mengambil $20 \%$ dari populasi peserta didik MAN 1 Kabupaten Bogor, yaitu sebanyak 40 responden di kelas XII. Alasan peneliti memilih kelas XII diantaranya karena kelas tersebut telah mengikuti seluruh materi pembelajaran PAI yang telah

\footnotetext{
${ }^{2}$ Sugiyono, Metode Penelitian Pendidikan (Pendekatan Kuantitatif, Kualitatif dan R\&D), 2017 hal.13

${ }^{3}$ Asep Saipul Hamdi, Metode Penelitian Kuantitatif Aplikasi Dalam Pendidikan, 2014, hal.7

${ }^{4}$ Dominikus Dolet Unaradjan, Metode Penelitian Kuantitatif, 2019, hal.112

${ }^{5}$ Suharsini Arikunto, Prosedur Penelitian (Suatu Pendekatan Praktik), 2013, hal.174
} 
diajarkan sesuai dengan kurikulum, dan telah mengikuti pembiasaanpembiasaan yang diprogramkan oleh sekolah.

B. Instrumen Penelitian

Pengumpulan data dalam penelitian ini menggunakan angket. Angket yang didefinisikan Angket adalah suatu teknik mengumpulkan data secara tidak langsung (peneliti tidak langsung bertanya-jawab kepada responden). Instrumen atau alat pengumpulan data disebut angket berisi pertanyaan atau pernyataan yang harus dijawab oleh responden. ${ }^{6}$ Dalam penelitian ini, sebuah angket dibagikan dengan pilihan jawaban atas pernyataan dalam bentuk skala likert, yaitu SL (Selalu), SR (Sering), KK (Kadang-Kadang), TP (Tidak Pernah) dengan 50 pertanyaan.

Tabel 1 Kisi-kisi Instrumen Variabel Religiusitas dan Adab Siswa

\begin{tabular}{|c|c|c|}
\hline Variabel & Indikator & item \\
\hline \multirow{4}{*}{ Religiusitas } & Akidah & 7 \\
\cline { 2 - 3 } & Praktik Ibadah & 6 \\
\cline { 2 - 3 } & Akhlak & 4 \\
\cline { 2 - 3 } & Pengetahuan agama & 6 \\
\hline \multirow{4}{*}{ Adab Siswa } & Penghayatan & 2 \\
\cline { 2 - 3 } & Adab Terhadap Allah SWT & 6 \\
\cline { 2 - 3 } & Adab Terhadap Orang Tua & 4 \\
\cline { 2 - 3 } & Adab Terhadap Guru & 5 \\
\cline { 2 - 3 } & Adab Terhadap Diri Sendiri & 3 \\
\hline
\end{tabular}

\section{Teknik Pengolahan Data}

Pengolahan Data yang telah terkumpul diolah terlebih dahulu melalui langkah-langkah berikut: 1). Editing, yaitu memeriksa daftar pertanyaan yang telah diisi oleh responden, 2). Skoring, Yaitu memberikan skor terhadap item-item pertanyaan pada angket, 3). Tabulating, Yaitu untuk mengetahui gambaran frekuensi dalam setiap item.

\section{Teknik Analisis Data}

Berdasarkan jenis data yang dikumpulkan yaitu data kuantitatif, maka teknik yang digunakan adalah analisis statistik, yaitu dengan cara statistik presentasi dan teknik korelasi. Teknik korelasi ini membahas dua variabel dengan menggunakan rumus korelasi product moment dari Karl Pearson.

\section{KAJIAN TEORI}

\footnotetext{
${ }^{6}$ Sukmadinata, Metode Penelitian Pendidikan, 2010
} 


\section{HASIL PENELITIAN DAN PEMBAHASAN}

\section{A. Religiusitas}

\section{Pengertian Religiusitas}

Religiusitas berasal dari kata religi dalam bahasa Latin "religio" yang akar katanya adalah religure yang berarti mengikat. Gazalba (1987) mengungkapkan bahwa religi atau agama pada umumnya mengandung makna atau memiliki aturan-aturan dan kewajibankewajiban yang harus dipatuhi dan dilaksanakan oleh pemeluknya. Kesemuanya itu berfungsi mengikat seseorang atau sekelompok orang dalam hubungannya dengan Tuhan, sesama manusia, dan alam sekitarnya. ${ }^{7}$

Muhaimin berpendapat bahwa Religiusitas dalam perspektif islam yaitu melaksanakan ajaran agama atau berislam secara menyeluruh. Sebagaimana firman Allah SWT dalam surat Al-Baqarah ayat 208:

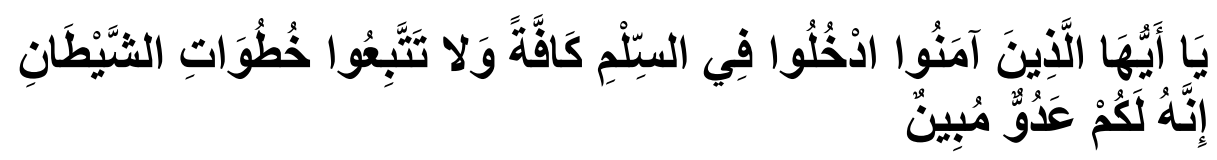

Artinya: "Hai orang-orang yang beriman, masuklah kamu ke dalam Islam secara keseluruhannya, dan janganlah kamu turut langkah-langkah setan. Sesungguhnya setan itu musuh yang nyata bagimu."

Berdasarkan definisi-definisi di atas dapat disimpulkan bahwa pengertian religiusitas adalah kedalaman beragama dan keyakinan seseorang akan adaya Tuhan yang diwujudkan dengan cara mematuhi perintah dan menjauhi segala larangannya dengan ikhlas, mengerahkan seluruh jiwa dan raga untuk mengabdi serta menginternalisasikan nilai-nilai agama dalam kehidupan sehari-hari. Religius hanya nampak ketika seseorang melaksanakan tuntutan agama dan menjaga akhlak dengan sesama.

\section{Aspek-Aspek Religiusitas}

Spinks (1963) mengatakan bahwa agama meliputi keyakinan, adat, tradisi dan juga pengalaman-pengalaman individual. Pembagian dimensi-dimensi religiusitas menurut Glock dan Stark terdiri dari lima dimensi, diantaranya: ${ }^{8}$

1. Dimensi Keyakinan (The Ideological Dimension) Yaitu tingkatan sejauh mana individu menerima dan mengakui hal-hal yang dogmatik dalam agamanya.

2. Dimensi Peribadatan atau Praktik Agama (The Ritualistic Dimension) Yaitu tingkatan sejauh mana individu dapat menunaikan kewajiban-kewajiban ritual dalam ajaran agamanya.

3. Dimensi Feeling atau Penghayatan (The Experiencal Dimension) Perasaan keagamaan yang pernah dialami atau dirasakan oleh seseorang. ${ }^{9}$

\footnotetext{
${ }^{7}$ Ghufron, Teori-teori Psikologi, 2010 hal. 167

${ }^{8}$ Ghufron. Op. cit. hal.169

${ }^{9}$ Imas Kania Rahman, Bimbingab Konseling Gestalt Profentik (Konsep, Praktik Bimbingan dan Konseling Islami), 2018, hal. 164
} 
4. Dimensi Pengetahuan Agama (The Intellectual Dimension) Keterlibatan seseorang menyangkut seberapa jauh memahami dan mengerti tentang ajaran agamanya, dan sejauh mana seseorang itu mengaplikasikan pemahamannya yang berkaitan dengan ajaran agama. ${ }^{10}$

5. Dimensi Effect atau Pengamalan (the consequential dimension). Dimensi pengalaman yaitu sejauh mana implikasi ajaran agama yang mampu mempengaruhi prilaku seseorang pada kehidupan sosial. ${ }^{11}$

\section{Indikator Religiusitas Seseorang}

Lebih lanjut Muhammad Alim (2006: 12) mengungkapkan untuk mengukur dan melihat sesuatu yang dapat menunjukkan sikap religius atau tidak, dapat dilihat dari karakteristik sikap religius. Oleh karena itu ada beberapa hal yang dapat dijadikan indikator sikap religius seseorang, yakni:

a. Komitmen terhadap perintah Allah dan larangan Allah (janji Allah terhadap manusia ketika menaati segala perintahnya)

b. Bersemangat untuk mengkaji ajaran agama (belajar agama)

c. Aktif dalam kegiatan agama

d. Menghargai simbol-simbol keagamaan

e. Akrab dengan kitab suci (selalu membaca al quran)

f. Mempergunakan pendekatan agama dalam menentukan pilihan (qur'an sunnah dan ijma sebagai patokan)

\section{B. Adab Siswa}

\section{Pengertian Adab}

Dalam Kamus Besar Bahasa Indonesia (Bahasa, 2003) kata adab, didefinisikan sebagai: kesopanan, kehalusan dan kebaikan budi pekerti, dan akhlak. ${ }^{12}$ Sedangkan beradab diartikan sebagai sopan, baik, budi bahasa, dan telah maju tingkat lahir dan batinnya. ${ }^{13}$

Selain itu adab juga merupakan salah satu istilah yang identik dengan pendidikan Akhlak, bahkan Ibn Qayyim berpendapat bahwa adab adalah inti dari akhlak, karena di dalamnya mencakup semua kebaikan (اجتمع حصال الخير ) 14

Menurut KH. Hasyim Asy'ari dalam bukunya yang berjudul Aadabul 'Aalim walMuta'allim menjelaskan bahwa kata adab merupakan ciri khas maknanya dalam Islam. Adab terkait dengan iman dan ibadah dalam Islam. Adab bukan sekadar sopan santun atau baik budi bahasa saja. ${ }^{15}$

Jadi pengertian adab adalah pengetahuan tentang sopan santun, aklak yang baik yang membantu diri sendiri dari segala sifat yang salah

\footnotetext{
${ }^{10}$ Imas Kania Rahman, Op. Cit. Hal 164

${ }^{11}$ Ghufron. Op. cit, hal. 171

12 Tim Bahasa, Kamus Besar Bahas Indonesia, 2003, hal.6

${ }^{13}$ Adian Husaini, Filsafat Ilmu (Perspektif Barat dan Islam), 2013, hal. 211

${ }^{14}$ Akhmad Halim, Studi Islam IV: Islamisasi Ilmu Kesehata, 2016, hal. 50

${ }^{15}$ Adian Husaini, Op. cit, hal. 219
} 


\section{Ruang Lingkup Adab}

a. Adab kepada Allah SWT

b. Adab kepada orang tua

c. Adab kepada guru

d. Adab kepada diri sendiri

e. Adab kepada teman

\section{Karakteristik Adab Seseorang}

Thouless (2000) menyebutkan bahwa religius dipengaruhi oleh beberapa faktor, yaitu:

a. Faktor sosial, yaitu meliputi pendidikan atau pengajaran yang mencakup semua pengaruh sosial dalam perkembangan sikap keagamaan, seperti pendidikan orang tua, tradisi-tradisi yang disesuaikan dan disepakati oleh lingkungan tempat tinggal

b. Berbagai macam pengalaman yang dialami oleh setiap individu dalam membentuk sikap keagamaan

c. Faktor-faktor yang timbul dari kebutuhan-kebutuhan yang tidak terpenuhi, terutama kebutuhan akan keamanan, cinta kasih, harga diri, dan ancaman kematian.

d. Faktor intelektual yaitu hal-hal yang berhubungan dengan proses pemikiran verbal terutama dalam pembentukan keyakinan-keyakinan keagamaan. (Rahmawati, 2016) ${ }^{16}$

\section{SIMPULAN}

Analisis awal dalam penelitian ini adalah pengujian prasyarat meliputi uji normalitas data dan uji linieritas.

\section{A. Uji Normalitas}

Uji normalitas pada penelitian ini dilakukan dengan teknik KolmogrovSmirnov.

Tabel 2 Hasil Uji Normalitas

One-Sample Kolmogorov-Smirnov Test

\begin{tabular}{llr} 
& & \multicolumn{1}{c}{$\begin{array}{c}\text { Unstandardize } \\
\text { d Residual }\end{array}$} \\
\hline $\mathrm{N}$ & Mean & 40 \\
\cline { 2 - 3 } Normal Parameters & a,b &, 0000000 \\
\hline Most Extreme Differences & Std. Deviation & 5,50621926 \\
\cline { 2 - 3 } & Absolute &, 076 \\
\cline { 2 - 3 } & Positive &, 076 \\
\hline Test Statistic & Negative &,- 070 \\
\hline Asymp. Sig. (2-tailed) & &, 076 \\
\hline
\end{tabular}

${ }^{16}$ Heny Kristiana Rahmawati “Kegiatan Religiusitas Masyarakat Marginal di Argopuro” Community Development, Vol 1, No. 2, 2016, hal.38 

a. Test distribution is Normal.
b. Calculated from data.
c. Lilliefors Significance Correction.
d. This is a lower bound of the true significance.

Berdasarkan tabel di atas dapat diketahui bahwa nilai signifikansi (Asymp, Sig 2 Tailed) sebesar 0,200. Karena nilai signifikansi lebih dari 0,05 $(0,200>0,05)$, maka data berdistribusi normal dan uji instrumen prasyarat terpenuhi.

\section{B. Uji Linieritas}

Uji linieritas yang dimana tujuannya untuk mengetahui hubungan dua variabel yang linier secara signifikan atau tidak, yaitu dengan cara membandingkan nila Deviation from linearity Sig $>0,05$. Jika data lebih dari 0,05 , maka data tersebut memiliki hubungan yang linier.

Tabel 3 Hasil Uji Linieritas

\begin{tabular}{|c|c|c|c|c|c|c|c|}
\hline \multicolumn{8}{|c|}{ ANOVA Table } \\
\hline & & & $\begin{array}{l}\text { Sum of } \\
\text { Squares }\end{array}$ & $d f$ & $\begin{array}{c}\text { Mean } \\
\text { Square }\end{array}$ & $\mathrm{F}$ & Sig. \\
\hline $\begin{array}{c}\text { Adab } \\
\text { Siswa * }\end{array}$ & $\begin{array}{l}\text { Between } \\
\text { Groups }\end{array}$ & (Combined) & 1924,267 & 21 & 91,632 & 4,348 & ,001 \\
\hline \multirow[t]{4}{*}{ Religiusitas } & & Linearity & 1121,180 & 1 & 1121,180 & 53,202 & ,000 \\
\hline & & $\begin{array}{c}\text { Deviation } \\
\text { from } \\
\text { Linearity }\end{array}$ & 803,086 & 20 & 40,154 & 1,905 & ,087 \\
\hline & $\begin{array}{l}\text { Within } \\
\text { Groups }\end{array}$ & 379,333 & 18 & 21,074 & & & \\
\hline & Total & 2303,600 & 39 & & & & \\
\hline
\end{tabular}

Dari tabel di atas dapat dilihat bahwa signifikansi pada Deviation From Linearity lebih dari 0,05 (0,78>0,05. Maka, data tersebut linier dan terdapat hubungan antara variabel religiusitas terhadap adab siswa di MAN 1 Kabupaten Bogor.

\section{Statistik Presentasi}


Tabel 4 Skor Rata-Rata dan Prosentase Angket

\begin{tabular}{|c|c|c|c|c|}
\hline Variabel & Indikator & Nilai Harap & Nilai Skor & $\frac{N S}{N H} \times 100$ \\
\hline \multirow{5}{*}{ Religiusitas } & Akidah & $7 \times 4=28$ & $\begin{array}{c}995: 40= \\
24,875\end{array}$ & $\frac{24,875}{28} \times 100=88,83 \%$ \\
\hline & Praktik Ibadah & $6 \times 4=24$ & $\begin{array}{c}782: 40= \\
19.55\end{array}$ & $\frac{19,55}{24} \times 100=0,81 \%$ \\
\hline & Akhlak & $4 \times 4=16$ & $\begin{array}{c}567: 40= \\
14,175\end{array}$ & $\frac{14,175}{16} \times 100=0,88 \%$ \\
\hline & $\begin{array}{l}\text { Pengetahuan } \\
\text { Agama }\end{array}$ & $4 \times 4=16$ & $\begin{array}{c}554: 40= \\
13,85\end{array}$ & $\frac{13,85}{16} \times 100=0,86 \%$ \\
\hline & Penghayatan & $4 \times 4=16$ & $\begin{array}{c}512: 40= \\
12,8\end{array}$ & $\frac{12,8}{16} \times 100=0,8 \%$ \\
\hline Hasil & & 100 & 85,25 & $\frac{85,25}{100} \times 100=85,25 \%$ \\
\hline \multirow{5}{*}{$\begin{array}{l}\text { Adab } \\
\text { Siswa }\end{array}$} & $\begin{array}{l}\text { Adab terhadap } \\
\text { Allah SWT }\end{array}$ & $7 \times 4=28$ & $\begin{array}{c}914: 40= \\
22,85\end{array}$ & $\frac{22,85}{28} \times 100=81,6 \%$ \\
\hline & $\begin{array}{l}\text { Adab terhadap } \\
\text { Orang tua }\end{array}$ & $6 \times 4=24$ & $\begin{array}{c}798: 40= \\
19,95\end{array}$ & $\frac{19,95}{24} \times 100=83,12 \%$ \\
\hline & $\begin{array}{l}\text { Adab terhadap } \\
\text { guru }\end{array}$ & $4 \times 4=16$ & $\begin{array}{c}538: 40= \\
13,45\end{array}$ & $\frac{13,45}{16} \times 100=84,06 \%$ \\
\hline & $\begin{array}{l}\text { Adab terhadap } \\
\text { diri sendiri }\end{array}$ & $5 \times 4=20$ & $\begin{array}{c}383: 40= \\
9,575\end{array}$ & $\frac{9,575}{20} \times 100=47,87 \%$ \\
\hline & $\begin{array}{l}\text { Adab terhadap } \\
\text { teman }\end{array}$ & $3 \times 4=12$ & $\begin{array}{c}663: 40= \\
16,575\end{array}$ & $\frac{16,575}{12} \times 100=137,5 \%$ \\
\hline Hasil & & 100 & 82,4 & $\frac{82,4}{100} \times 100=82,4 \%$ \\
\hline
\end{tabular}

Berdasarkan data di atas menyatakan bahwa skor akhir rata-rata prosentase variabel bernilai $85,25 \%$ untuk variabel religiusitad dan skor $82,4 \%$ untuk variabel peserta didik.

\section{Teknik Korelasi}

Rumus statistik yang digunakan untuk mencari data dan mengetahui ada tidaknya hubungan antara kedua variabel ialah rumus korelasi "Product Moment", karena dalam penelitian ini terdapat dua variabel yang perlu mendapat kejelasan, apakah terdapat hubungan antara kedua variabel atau tidak terdapat hubungan. Kedua variabel tersebut ialah religiusitas dan adab siswa. 


\section{Correlations}

\begin{tabular}{llr|r} 
& & \multicolumn{1}{c}{ Religiusitas } & \multicolumn{1}{c}{ Adab Siswa } \\
\hline \multirow{2}{*}{ Religiusitas } & Pearson Correlation & 1 &, $698^{* *}$ \\
\cline { 2 - 4 } & Sig. (2-tailed) & &, 000 \\
\cline { 2 - 4 } & $\mathrm{N}$ & 40 & 40 \\
\hline \multirow{2}{*}{ Adab Siswa } & Pearson Correlation &, $698^{* *}$ & 1 \\
\cline { 2 - 4 } & Sig. (2-tailed) &, 000 & \\
\cline { 2 - 4 } & $\mathrm{N}$ & 40 & 40 \\
\hline
\end{tabular}

**. Correlation is significant at the 0.01 level (2-tailed).

Berdasarkan hasil analisis data yang telah dilakukan dengan teknik analisis korelasi Product Moment dari Pearson yang dibantu dengan menggunakan program SPSS 26.0 For Windows dapat diketahui nilai koefisien korelasi (r) sebesar 0,698 dan sig. $=0,000 ; \mathrm{p}<0,01$, sehingga menunjukan adanya hubungan positif yang sangat signifikan antara religiusitas terhadap adab siswa. Berdasarkan data tersebut, maka hipotesis yang diajukan oleh peneliti dapat diterima.

Setelah uji hipotesis dilakukan, untuk mengetahui seberapa besar pengaruh religiusitas terhadap adab siswa di MAN 1 Kabupaten Bogor, maka digunakan rumus "Koefisien Determinasi" yang dinyatakan dengan rumus berikut:

$$
\begin{aligned}
\mathrm{KD}= & \mathrm{r} 2 \times 100 \% \\
\mathrm{KD}= & (0,60) 2 \times 100 \% \\
& =0,36 \times 100 \% \\
& =36 \%
\end{aligned}
$$

Kesimpulan yang dapat diambil adalah pengaruh religiusitas berpengaruh terhadap adab siswa di MAN 1 Kabupaten Bogor sebesar 36\% dan 64\% dipengaruhi oleh faktor lainnya.

\section{DAFTAR PUSTAKA}

Bafadhol , I. (2017 ). Pendidikan Akhlak dalam Perspektif Islam. Edukasi Islami Jurnal Pendidikan Islam, Vol. 06 No.12.

Bahasa, T. P. (2003). KBBI. Jakarta: Balai Pustaka.

Ghufron, R. (2010). Teori-Teori Psikologgi. Jogjakarta: Ar-Ruzz Media.

Halim, D. (2016). STUDI ISLAM IV Fakultas Kesehatan: Islamisasi Ilmu Kesehatan . Bogor: UIKA Press.

Hamdi, A. S. (2014). Metode Penelitian Kuantitatif Aplikasi Dalam Pendidikan. Yogyakarta: Deepublish. 
Husaini, A. (2013). Filsafat Ilmu (perspektif Barat dan Islam). Depok: Gema Insani.

Rahman, I. K. (2018). Bimbingan \& Konseling Gestalt Profentik (Konsep, Praktik Bimbingan dan Konseling. Bogor: UIKA PRESS.

Rahmawati, H. K. (2016). Kegiatan Religiusitas Masyarakat Marginal di Argopuro. Community Development, Vol. 1, No.2.

Sugiyono. (2017). Metode Penelitian Pendidikan (Pendekatan Kuantitatif, Kualitatif dan $R \& D)$. Bandung: Alfabeta.

Sukmadinata, N. S. (2010). Metode Penelitian Pendidikan. Bandung: PT Remaja Rosdakarya.

Unadjaran, D. D. (2019). Metode Penelitian Kuantitatif. Jakarta: Penerbit Universitas Katolik Indonesia Atma Jaya. 